\title{
ランチョンセミナー 4
}

共催：北陸製薬株式会社/藤沢薬品工業株式会社

日時：第 1 日 11 月 10 日（金） $12: 00 \sim 12: 55$

場所 : 第 7 会場（エルガーラ大ホール 8 階）

\section{「ポリカルボフィルと過敏性腸症候群」}

演者：東北大学総合諮療部

司会 : 九州大学臨床・腫場外科
本 郷 道 夫

田中 雅 夫

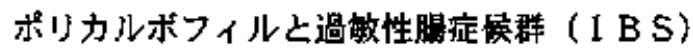

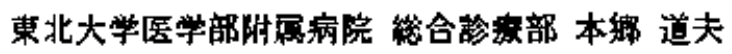

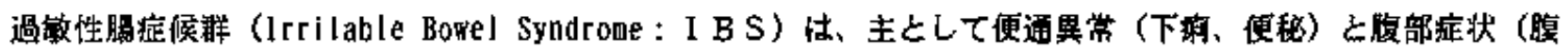

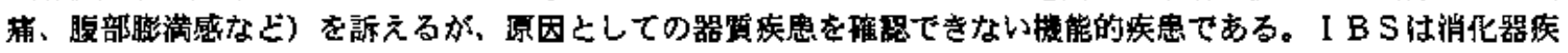
患の中でも恢度の高い疾患であり、モの発生には精神的要因やストレス等の社会晨愤が関与していることから、 今後も益を增加することが予热さずる。

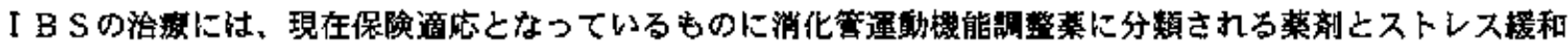
を目的とした抗不安薬方ある。しかし、十分な治療效果が得られない症洌も決して少なくはない。ボリカルがフ

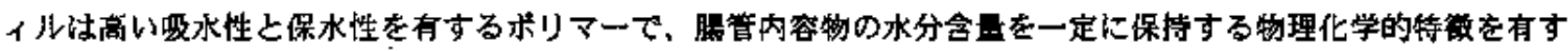
る。この性状を利用して、便性状のコントロールを介して便通暴常を改善し、I B S の治䒺か試みられた。

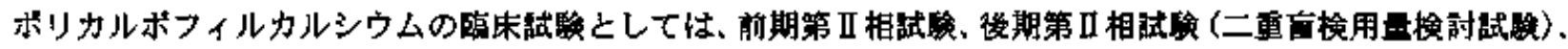

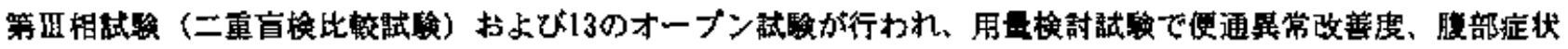

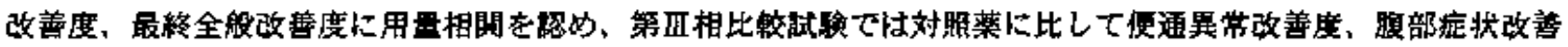

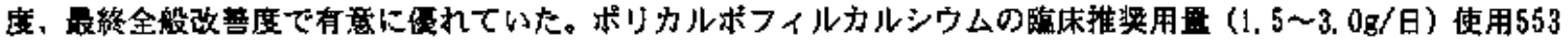

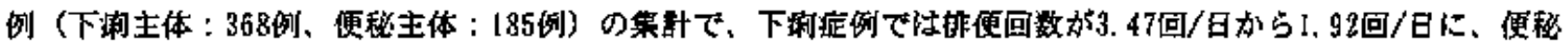

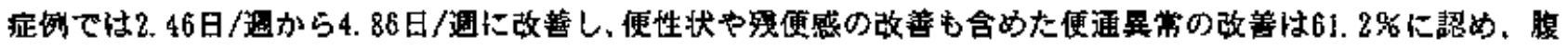

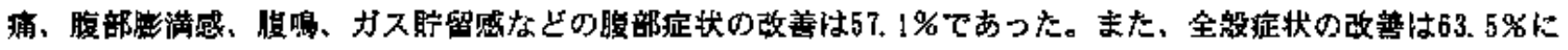

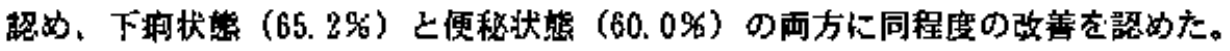

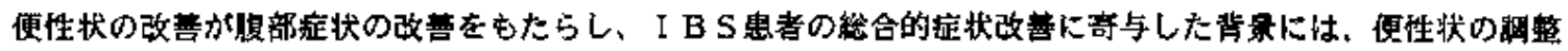

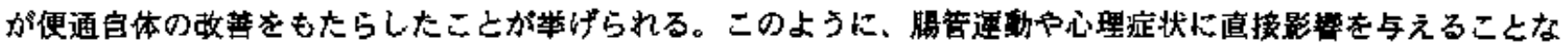

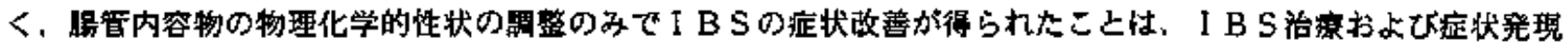
譏序を考える上で霄要な所見である。 